\title{
Dynamic capabilities from an institutionalist viewpoint
}

\author{
José Bonfim Albuquerque Filho \\ Universidade Federal do Paraná / Programa de Pós-Graduação em Administração, Curitiba- PR, Brazil \\ SERGio Bulgacov \\ Fundação Getulio Vargas / Escola de Administração de Empresas de SÃo Paulo, SÃo Paulo- SP, Brazil
}

MÁRCIA RAMOS MAY

Universidade federal do Paraná / Programa de Pós-Graduação em Administração, Curitiba- PR, Brazil

\begin{abstract}
The purpose of this paper is to elucidate the effects of strategic, technical and institutional response, in the perspective of dynamic capability facing environmental changes, considering that the literature has few references on how institutional factors contribute to a firm's dynamic capabilities. A case study was conducted on the oldest journalistic enterprise in Brazil. It was found that the organizational practices with dynamic capabilities were conditioned by mechanisms and factors that have extrapolated intentions, expectations, and planning skills of the firm's own Board of Directors. The new social structure found in the organization is based on the interpretations of the journalists themselves, regarding the social reality of the field of journalism, was supported by the coherent interpretative schemata of some managers in order to reduce the uncertainty caused by institutional demands of the rapidly changing reading habits of people. The study revealed that strategic practices such as making the newspaper known at schools, development of a digital newspaper, showed the influence of institutions as a new normative order, social responsibility, greater legitimacy, and at the same time, a higher capacity of the organization to adapt to its business environment. These aspects, reflect a cultural structure that is reproduced at the company in its practices for the continuous use of new technologies and new social demands.
\end{abstract}

Keywords: Dynamic Capabilities. Institutions. Organizational practices.

\section{Capacidades dinâmicas de um ponto de vista institucionalista}

\section{Resumo}

O objetivo deste artigo é elucidar os efeitos das respostas estratégica, técnica e institucional na perspectiva das capacidades dinâmicas tendo em vista as mudanças ambientais, considerando que a literatura tem apresentado poucas referências sobre como os fatores institucionais contribuem para a capacidade dinâmica. Um estudo de caso foi realizado na mais antiga empresa jornalística no Brasil. Identificou-se que as práticas organizacionais, na perspectiva da capacidade dinâmica são condicionadas por mecanismos e fatores que extrapolam intenções, expectativas e habilidades de planejamento anteriores da Diretoria. A nova estrutura social da organização, desvelada pelo estudo, baseada na interpretação dos próprios jornalistas, a respeito da realidade social do campo do jornalismo, apoiado pela interpretação coerente de alguns dos gestores, foi sendo institucionalizada ao se buscar reduzir as incertezas causadas pela rápida mudança nos hábitos de leitura das pessoas. O estudo revelou que novas práticas estratégicas, tais como levar o jornal a ser conhecido por escolares e o desenvolvimento de um jornal digital, demonstraram a institucionalização de novas ordens normativas com maior responsabilidade social, maior legitimidade e, ao mesmo tempo, maior capacidade da organização em se adaptar ao novo ambiente de negócio. Em outra perspectiva, esses aspectos refletem uma estrutura cultural que contribui para direcionamento da empresa para o uso de novas tecnologias e demandas sociais.

Palavras-chave: Capacidades dinâmicas. Instituições. Práticas organizacionais.

\section{Capacidades dinámicas desde un punto de vista institucionalista}

\section{Resumen}

El objetivo de este artículo es dilucidar los efectos de las respuestas estratégica, técnica e institucional en la perspectiva de las capacidades dinámicas, teniendo en cuenta los cambios ambientales, considerando que la literatura ha presentado pocas referencias sobre cómo los factores institucionales contribuyen a la capacidad dinámica. En un estudio de caso realizado en la empresa periodística brasileña más antigua, se identificó que las prácticas organizacionales, en la perspectiva de la capacidad dinámica están condicionadas por mecanismos y factores que superan intenciones, expectativas y habilidades de planificación anteriores de la dirección. La nueva estructura social de la organización, develada por el estudio, basada en la interpretación de los propios periodistas acerca de la realidad social del campo del periodismo, apoyada por la interpretación coherente de algunos de los gestores, fue siendo institucionalizada al buscar reducir la incertidumbre causada por el rápido cambio de los hábitos de lectura de las personas. El estudio reveló que nuevas prácticas estratégicas, tales como hacer que el periódico sea conocido por estudiantes y el desarrollo de un periódico digital, demostraron la institucionalización de nuevos órdenes normativos con mayor responsabilidad social, mayor legitimidad y, al mismo tiempo, mayor capacidad de la organización para adaptarse al nuevo ambiente de negocio. En otra perspectiva, estos aspectos reflejan una estructura cultural que contribuye a dirigir a la empresa hacia el uso de nuevas tecnologías y demandas sociales.

Palabras clave: Capacidades dinámicas. Instituciones. Prácticas organizacionales. 


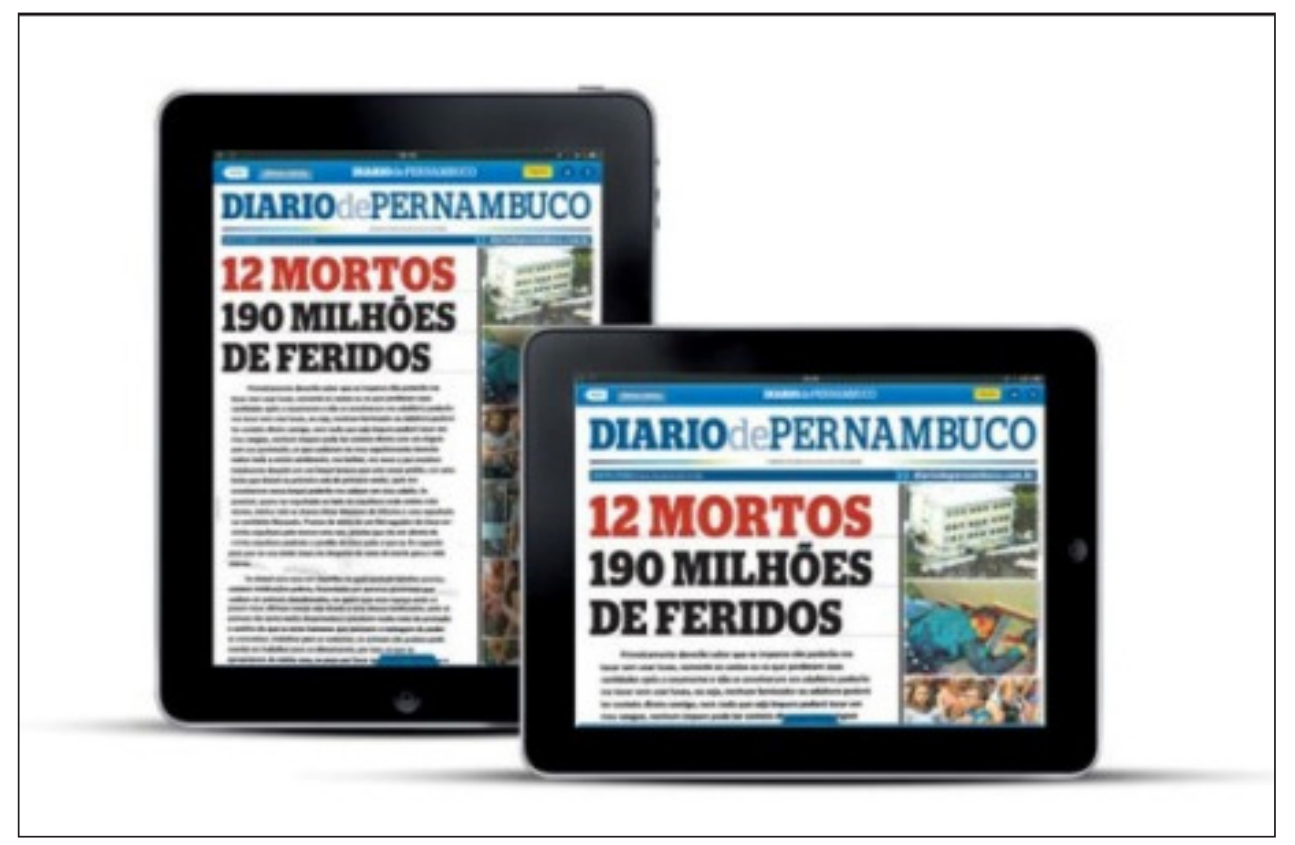

\section{INTRODUCTION}

Studies of journalistic media companies have sought to monitor the online dynamic, which has changed habits and posed a challenge to working conditions. They seek to understand, using a variety of paradigms and multiple disciplines, the construction and reconstruction process of this field. However, this cannot be done without facing problems, such as those that confront print media, which face threats and opportunities in the light of changing reading habits and the revolutionized way that news is now made in time and space. According to Alcadipani $(2007$, p. 30), "few sectors have suffered as much from advancing information technology as newspapers". On such evidence, Meyer (2009) reissued the book entitled The Vanishing Newspaper, highlighting the concerns of society worldwide regarding the survival of newspapers. Indeed, for a long time, newspapers had monopolized access to information. However, the new forms of media that arise constantly bring in their wake the demise of this means of circulating information. A greater cause for concern is that this could even lead to the weakening of democracy, according to the authors of The Death and Life of American Journalism (MCCHESNEY and NICHOLS, 2010).

The fact is that journalism firms are facing the greatest crisis in their history. Renowned international daily newspapers such as Le Monde, The Guardian, The New York Times and the oldest newspaper in the world, The Times, have attempted to reverse the situation, but with little success. Quinn (2005) points out that many of the strategies used by the media are based on changing reading habits. Furthermore, Alcadipani (2007), suggests that these changes, which are the result of technological innovations, are reflected not only in losing readers to competing newspapers, but also to other forms of media, or even new interests, habits and institutions.

These changes are not limited to developed countries, since internet is a worldwide reality. The Brazilian journalism sector, like other countries, has the biggest firms that are over a hundred years old. Until early 2012, 26 firms had survived for over a century, publishing over 4000 printed newspapers that are now feeling the pressures of the internet. 
Therefore, despite the announcement of positive results in 2008 by the National Newspaper Association (ANJ), newspapers that enjoy a wide circulation, such as A Folha de S. Paulo and O Globo, from 2008 to 2009 lost around seven percent (7\%) of their average daily readership. The Jornal do Brasil announced the end of its printed edition and went totally digital on the first day of September, 2010.

In this context, the aim of this study is to analyze the technical and institutional responses from a dynamic capabilities perspective, in the light of environmental changes, at the oldest Brazilian journalism firm.

It is important to point out, based on the literature, that organizations are capable of attempting to respond to these influences creatively and strategically. The institutional theory, for instance, attempts to map directions that these changes are taking. In turn, strategic theories, concerned also with responses to environmental conditions, extrapolate exclusive concerns with strategic studies and empower organizations with dynamic capabilities that enable them to respond quickly to rapidly changing technologies.

Despite these evolving theories, the changes are more challenging. In addition to the rapid changes in computer processes, institutional changes are also evident, especially in the digital media. Therefore, technological changes that directly affect expressive institutional changes give rise to the converging literatures that seek to explain organizations through the technical dimension of the environment and those that attempt to do so through the institutional facet.

In this sense, a theoretical aspect is revealed, which is to establish a dialogue between these concepts that have developed separately in the institutional theory and in the literature regarding dynamic capabilities. This is because little attention has been paid to the combination of these theoretical perspectives, except for isolated articles such as that of McKague (2011), which deals specifically with institutional entrepreneurship.

It is understood that this research can help clarify an overlap that presumably exists in the distinct literature. On the one hand is the institutional theory which, despite recognizing the influence of technical and institutional aspects of the context, focused more on institutional pressures and restrictions. On the other hand, literature on dynamic capabilities tends to place more emphasis on the technical environment, where rapid technological development requires the emergence of adequate capabilities, even though they do not ignore the social environment that surrounds organizations. Theoretical limits, where the tendency of organizational isomorphism's, as defended by institutionalists, can overlap with the need for idiosyncratic resources constructed by organizations with dynamic capabilities. This clarification of the grey zone will definitely strengthen the current trend of action and structure in the institutional theory, shedding light on the convergent capabilities of individual choices and organizational passiveness when facing contextual structures.

For this purpose, the discussion begins with the development of studies of dynamic capabilities in face of organizational strategy. This will be followed by common points of interest between the literature of dynamic capabilities and institutional theory. This will serve as a basis for proposing an analytical model of dynamic capabilities in which aspects of an institutional nature are considered. The model will then be tested in the case study.

\section{THE DYNAMIC CAPABILITIES APPROACH}

According to Teece, Pisano and Shuen (1997), dynamic capability is the "ability to integrate, build and reconfigure internal and external competencies to address rapidly changing environments" (p. 516). These capabilities become the source of sustainability of the competitive will, rather than the simple maintenance of a profitable position (Porter, 1985) or of resources being valuable, rare, inimitable and non-substitutable (BARNEY, 1991; 1996; WERNERFELT, 1984).

Other definitions arose, such as those of Eisenhardt and Martin (2000, p. 1107), to whom dynamic capabilities are "the firm's processes that use resources ... to match and even create market change." In 2002, Zollo and Winter focused on organizational learning as a source of dynamic capability. To these authors, this capability is like "a learned and stable pattern of collective activity through which the organization systematically generates and modifies its operating routines in pursuit of improved effectiveness" (p. 340). Helfat, Finkelstein, Mitchel et al. (2007, p. 4) reconstructed the definition to "the capacity of an organization to purposefully create, extend or modify its resource base". In 2007, Teece introduced the micro foundations of 
dynamic capabilities, the distinct skills, processes, organizational procedures, structures, decision rules and disciplines that form the basis of these organizational capabilities. Evolutionary fitness (adaptation and anticipation to changing circumstances) is also required and dynamic capabilities can help organizations in that direction (LEIH and TEECE, 2016). To these authors, strategy takes on a broader function. For this reason, in addition to a competitive advantage, they included survival and growth as measurements of influence for dynamic capabilities.

The analytical support developed by the author can help scientists to understand the long-term success of a business and help managers of organizations to outline strategies to improve business performance.

\section{THE INSTITUTIONAL THEORY}

The classic article written by Meyer and Rowan (1977) prompted a radical change in the conventional modes of thinking regarding the formal structure of an organization. To these authors, structures carry socially shared meanings. The article highlighted limitations of these explanations regarding structure based only on rationality and lauded socially symbolic implications (TOLBERT and ZUCKER, 1999).

DiMaggio and Powell (1983), with the idea of structural isomorphism as an important consequence of the competitive and institutional process, demonstrated that organizations suffer continuous environmental pressures to become more homogeneous through pressures resulting from normative, coercive and mimetic institutional mechanisms.

In this panorama, the concept of legitimacy (the acceptance of an organization by its external environment) becomes a core concept of the institutional theory. Deephouse (1996) views legitimation as a process that means desires and norms when viewed through an evaluative perspective or accepted as truth when viewed from a cognitive perspective. From the viewpoint of a particular social actor, a legitimate organization is one whose values and actions are congruent with the values and expected actions of this actor (GALASKIEWICZ, 1979), i.e., the actor endorses the means and ends of the organization as valid, reasonable and rational.

Looking at organizational studies, Scott $(2001 ; 2008)$ emphasized institutions as being social structures that achieved a high degree of resilience, composed of normative, regulatory and cultural-cognitive elements that bring stability and meaning to social life. They operate at multiple levels of jurisdiction, from the worldwide system to interpersonal relationships. By definition, institutions imply stability, but are subject to incremental and revolutionary change processes (SCOTT, 2008). Institutions permeate organizations as social structures and are transported by drivers (JEPPERSON, 1991; SCOTT, 2008): symbolic systems, relational systems, routines and artifacts.

Initially, institutionalists gave priority to continuity and the coaction of social structures. They did not draw attention to the forms by which individual actors acted to create, maintain and transform institutions. Currently, many institutionalists highlight the ways in which individuals and organizations innovate, act strategically and contribute to institutional changes (SCOTT, 2008). In this sense, the influence of Giddens (2003) is perceived, with its duality of structure showing that structures are both a means and a result of the reproduction of social practices. Structures are coactive, but they are also enablers.

\section{JUSTIFICATION OF THE PROPOSED THEORETICAL INTERSECTION}

There is an epistemological encounter between both fields of literature. The current institutional vision of organizations is very close to the original institutionalists of Economics which, in turn, are part of the fundamental principles of Evolutionary Economics, the economic branch of dynamic capabilities. Following the specification of these converging points, Arend and Bromiley (2009) point out that dynamic capabilities require more underlying theory because it was developed in isolation from organizational theory. This leads to the assumption that, epistemologically, concepts of the theory of dynamic capabilities may be related to concepts developed within the institutional theory.

Chart 1 shows the points of interest shared by both literatures and possible complements can be substantiated, culminating in a proposal for integration. 


\section{Chart 1}

\section{Points of interest shared by the literature}

\begin{tabular}{|c|c|c|}
\hline Common Interest & Institutional Theory & Dynamic Capabilities \\
\hline $\begin{array}{l}\text { Institution - important } \\
\text { component of } \\
\text { organizational analysis. }\end{array}$ & Central concept of the institutional theory. & $\begin{array}{l}\text { Teece, Pisano e Schuen (1997) show that institutions, } \\
\text { although not necessarily specific to a given organization, } \\
\text { are critical when determining dynamic capabilities. }\end{array}$ \\
\hline $\begin{array}{l}\text { Technical and institutional } \\
\text { dimension of the } \\
\text { environment }\end{array}$ & $\begin{array}{l}\text { Technical and institutional dimensions of } \\
\text { the environment proposed by Meyer and } \\
\text { Rowan (1977) and accepted by almost all the } \\
\text { institutionalist community. }\end{array}$ & $\begin{array}{l}\text { Teece, Pisano e Schuen (1997) highlight that } \\
\text { institutions, together with the market, define the } \\
\text { environment in which organizations operate. }\end{array}$ \\
\hline $\begin{array}{l}\text { Relevance of } \\
\text { historiographic approaches }\end{array}$ & $\begin{array}{l}\text { The institutional theory highlights } \\
\text { organizational history, paying greater attention } \\
\text { to analyses over time (SCOTT, 2008). }\end{array}$ & $\begin{array}{l}\text { Teece, Pisano e Schuen (1997) recognize the } \\
\text { importance of organizational history in the notion of } \\
\text { path dependence adopted as a preponderant factor for } \\
\text { identifying dynamic capabilities. }\end{array}$ \\
\hline Legitimacy and reputation. & $\begin{array}{l}\text { To Scott, Ruef, Mendel and Caronna ( } 2000, \mathrm{p} \text {. } \\
237) \text {, success and survival, besides depending } \\
\text { on resources, "also need social credibility and } \\
\text { acceptability". To Deephouse and Suchman } \\
\text { (2008), legitimacy and reputation have much } \\
\text { in common. A good organizational reputation } \\
\text { is the incorporation of legitimate elements in } \\
\text { the environment. }\end{array}$ & $\begin{array}{l}\text { Teece, Pisano e Schuen (1997) value reputation } \\
\text { (reputational assets), as an intangible asset that enables } \\
\text { the organization to achieve several market goals, this } \\
\text { being a fundamental condition for defining certain } \\
\text { dynamic capabilities. }\end{array}$ \\
\hline $\begin{array}{l}\text { Interest in organizational } \\
\text { practices and repertoire of } \\
\text { routines. }\end{array}$ & $\begin{array}{l}\text { To institutionalists, organizational routines } \\
\text { and habitual behaviors are the fundamental } \\
\text { drivers of institutions (SCOTT, 2008). Nelson } \\
\text { and Winter (1982) show that routines "can } \\
\text { be treated as one mode of institutionalized } \\
\text { behavior" (SCOTT, 2008, p. 30). }\end{array}$ & $\begin{array}{l}\text { Dosi, Nelson and Winter (2009) explain the dynamic of } \\
\text { organizational capabilities in their research of routines as } \\
\text { skills of organizations. Pisano (2000) focused on dynamic } \\
\text { routines regulating improvements of other routines. } \\
\text { Eisenhardt and Martin (2000) studied routines of product } \\
\text { development and resource allocation as dynamic } \\
\text { capabilities. To Teece et al. (1997), the repertoire of } \\
\text { routines in an organization and path dependence outline } \\
\text { future actions and can even define certain capabilities. }\end{array}$ \\
\hline $\begin{array}{l}\text { Interest in standardized } \\
\text { rules stemming from } \\
\text { norms and values. }\end{array}$ & $\begin{array}{l}\text { According to Scott (2008), for institutionalists } \\
\text { who adopt, above all, the normative pillar, } \\
\text { many organizational actions are specified by } \\
\text { standard operating procedures (CYERT and } \\
\text { MARCH, 1963; MARCH and OLSEN, 1989). }\end{array}$ & $\begin{array}{l}\text { Helfat, Finkelstein, Mitchel et al. (2007) state that } \\
\text { standard operating procedures, as well as routines, } \\
\text { require dynamic capabilities that review them } \\
\text { periodically to support environmental changes. }\end{array}$ \\
\hline $\begin{array}{l}\text { Attention to cultural } \\
\text { and cognitive effects in } \\
\text { organizations }\end{array}$ & $\begin{array}{l}\text { Attention to the cultural and cognitive } \\
\text { dimensions of institutions is the most distinct } \\
\text { characteristic of neoinstitutionalists in the } \\
\text { field of organizational studies (DIMAGGIO and } \\
\text { POWELL, 1983; SCOTT, 2008) }\end{array}$ & $\begin{array}{l}\text { The research conducted by Helfat, Finkelstein, Mitchel } \\
\text { et al. (2007) at Rubbermaid and at Dell Computers } \\
\text { shows the culture behind executive behaviors and that } \\
\text { they are "robust dynamic capabilities" (p. 54), built } \\
\text { over time. The authors showed that a set of beliefs } \\
\text { founded on previous acquisitions, minimized dynamic } \\
\text { capabilities in the strategic changes that stemmed from } \\
\text { the acquisition of the Snapple Beverage Company by } \\
\text { Quaker Oats. }\end{array}$ \\
\hline
\end{tabular}

Source: Bibliographic research data. 
Therefore, the possibility of complementarity with the institutional theory may strengthen the presence of dynamic capabilities in the theory of organizations, allowing more mature theoretical bases for dynamic capabilities.

Helfat and Peteraf (2009) emphasize that the exclusivity of dynamic capabilities lies in the guidance of strategic issues regarding how to sustain a competitive advantage in contexts of organizational change. Nevertheless, these changes do not take place only within the technical dimension, but also in the institutional. In this sense, institutionalists have developed knowledge, according to Meyer and Rowan (1977), making it possible to borrow organizational concepts that lengthen the reach of dynamic capabilities beyond technological changes.

Arend and Bromiley (2009) criticize the dynamic capabilities approach for its teleological posture, focusing only on its endpoints and not considering many important factors that influence changes. This gap could certainly be narrowed or even bridged with the help of knowledge developed by the institutional theory in the concepts of institutionalization and deinstitutionalization.

The findings of Oliver (1991), regarding a comparison of the institutional theory and the resource based view (RBV), show that both emphasize legitimacy, one by obtaining more social convenience and the other, an instrumental legitimacy as an operational resource (SUCHMAN, 1995), for the purpose of mobilizing resources. The former relies on conformity with the institutional environment, and the RBV uses actions to control and resist the environment.

However, in the view of dynamic capabilities, the environment is highlighted as a dynamic matter, whereas it is not highlighted in such way so much by the RBV. In this dynamic environment, managerial control and resistance to change are more difficult, and also hinder legitimacy only as an operating resource (SUCHMAN, 1995). Organizations need conditions that enable them to sustain a competitive position over time, requiring more consolidated bases of legitimacy. Integration of concepts may mean that criticisms of polysemy of dynamic capabilities can be avoided, as stated by Arend and Bromiley (2009).

An interpretation of dynamic capabilities from the viewpoint of organizational institutionalists may explain better the definitions of Helfat, Finkelstein, Mitchel et al. (2007), using theoretical foundations already developed in organizational theory rather than "quoting dictionary definitions" (AREND and BROMILEY, 2009, p. 80).

\section{THE INTEGRATING PERSPECTIVE}

In the proposal for integration, there is an agreement with Teece (2007) that dynamic capabilities are indeed reflected in organizational practices of (a) sensing and shaping opportunities and threats; (b) seizing opportunities and (c) maintaining competitiveness. However, these capabilities, besides being supported by managerial and organizational processes of coordinating/integrating, learning and reconfiguring, are also allegedly influenced by institutional factors that act as basic ingredients in the rebuilding of these organizational practices. Thus, institutional factors and dynamic capabilities are related in the structuring of organizational practices, but this relationship occurs in a non-reflexive feedback cycle, i.e., the structuration of Antony Giddens (2003), in which dynamic capabilities are conditioned by institutional factors that persist or are continuously rebuilt through the action of these capabilities.

Figure 1 illustrates the proposal suggested by the study in an analytical model in which dynamic capabilities of the categories set by Teece (2007) (sensing/shaping; seizing; and maintaining) are related to institutional factors of the context that surrounds a given organization. This reconstruction of capabilities also reflects the duality described by Giddens (2003): structure and action. This process is constituted by the continuity, coaction and enabling function of structures and the actions of individual actors to create, maintain and transform them.

The presence of action in this process is based on the concept of agency, referring to the ability of an actor to produce some effect in the social aspects, changing rules or distributing resources, remembering that in the concept of agency, the fundamental premise is that "between the context and the response is the interpreting actor" (SCOTT, 2001, p. 76). 
Figure 1

Ingrated model: institutions and categories of dynamic capabilities

\begin{tabular}{|c|c|c|}
\hline \multirow{4}{*}{ INSTITUTIONS } & & DYNAMIC CAPABILITIES \\
\hline & $\leftarrow \rightarrow$ & Sense and/or Shape \\
\hline & $\leftarrow \rightarrow$ & Seize opportunities \\
\hline & $\leftarrow \rightarrow$ & Maintein competitivenes \\
\hline
\end{tabular}

Source: Elaborated by the authors.

Another important consideration is required regarding the intention of the agent, since capacity for agency is defined as the power to intervene in the course of events or in the state of things without necessarily having any intention. As proposed by Giddens $(1993 ; 2003)$, intention is a relevant aspect, but is not sufficient to explain this ability.

\section{METHODOLOGICAL PROCEDURES}

For the case study, Diário de Pernambuco S.A. was selected. This organization was chosen following an exploratory analysis of the context of the journalism sector in Brazil. It is the longest surviving company in the field of journalism in South America, being over 186 years old and publishing the oldest Portuguese language newspaper in the world. It is considered unique, above all because it has undergone several periods of technological and institutional changes, surviving through a number of crises and remaining successful, with two newspapers that enjoy a wide circulation. It was therefore considered academically significant, especially because during the exploratory stage it showed signs of dynamic capabilities in its strategic process, based on the search and the renewal of its readers.

Initially, data were collected from secondary sources, affording insight into the context of print media in Brazil. The history of Brazilian journalism was obtained from the works of historians dedicated to the study of this field, especially Sodré (1994), Morel (2008), Martins (2008), Barbosa (2007), Ortriwano (2002/2003), Hohlfeldt, Valles (2008).

Likewise, the subjects related to the recent changes in journalism as a result of the growth of internet, such as appearance of digital media, the crisis faced by the print media and the dawn of online journalism, were researched in specialized writings such as those of Kucinski (2005), Boczkowski (2004), Meyer (2009) and the Brazilian sources, including Dornelles (2009), Righetti and Quadros (2007) and Melo (2009).

Given the dynamic status of the field and the lack of academic works and literature on the theme, updated sources of data were used, such as reports and interviews filed at the Press Observatory (OI) and the National Newspaper Association (ANJ), in addition to data retrieved from market sources, such as the Circulation Verification Institute (IVC), Mídia Dados and official government sources such as the IBGE (Brazilian Institute of Geography and Statistics), always seeking to verify data using more than one source.

Data were also collected that enabled a historiographic study stretching back to when the company was founded. However, greater attention was paid to the period since the advent of the internet, i.e., from 1997 to 2012. As a result, multiple sources of information (CRESWELL, 2002) were used, including semi-structured interviews, secondary data from registries and archives, photographs, videos and physical artifacts. Reports were also prepared following direct observations made during visits to the organization. 
The interviews served three purposes: to collect data to enable a description of organizational practices classified into previously defined categories; to complement and validate secondary data collected through the analysis of documents; and especially, following the suggestion of Machado-da-Silva, Fonseca and Crubellate (2005), to gauge the interpretation of the managers regarding the practices and relationships under study in the context of Diário de Pernambuco S.A. Data were collected from October of 2011 until july of 2012.

The main sources of data for the qualitative stage were: five books that had been published about the Diário de Pernambuco newspaper, reports from the Diários Associados (Associated Dailies) and the National Newspaper Association (ANJ), interviews divulged by the ANJ and the Press Observatory (OI) and interviews conducted by the author with 5 executives and 4 journalists from the company in question, visits to two local schools that participated in the projects of the company and visits to the company facilities. A validation of the data collected was asked to be confirmed by the respondents on a second interview.

In the case study, a range of practices that constitute this strategic process are examined. The study is sectional in nature with longitudinal evaluation, as past events were recalled through interviews and a historiographic analysis. This longitudinal resource was important because dynamic capabilities and institutions are better understood over time. This also accounts for the choice of a secular company.

Methodologically, the identification of strategic process practices of organization was based on the concept of social practice of Giddens (1993), and according with Albuquerque Filho and Machado-da-Silva (2009), on the organizational. To these authors, these practices are regular and recurring social practices that continuously build and rebuild a social system in space and time. In this case, the social system is that of the specific organization under study.

The categories of practices were determined in accordance with Teece (2007), i.e., the three groups of activities that belong to dynamic capabilities. Chart 2 summarizes practices in their respective categories.

\section{Chart 2}

\section{Practices of the strategic process}

\begin{tabular}{|c|c|}
\hline Categories & Practice \\
\hline \multirow{3}{*}{$\begin{array}{c}\text { Sensing and/or shaping the } \\
\text { environment }\end{array}$} & Project to divulge the newspaper in schools \\
\cline { 2 - 2 } & The action of journalists in discovering new technologies \\
\cline { 2 - 2 } Seizing opportunities & Participation at ANJ events \\
\cline { 2 - 2 } & Development of a new product and new business: Aqui PE \\
\hline Maintaining competitiveness & Practice of "online journalism" \\
\hline
\end{tabular}

Source: Research data.

\section{GENERAL CHARACTERIZATION OF THE CASE AND ANALYSIS: DIÁRIO DE PERNAMBUCO S.A.}

The context of journalism in Brazil has been developing since 1808, with the founding of Imprensa Régia. Since those times, there have been many institutional and technological changes in the sector up to and including the arrival of the internet, which has come to change the millennial institution of reading from paper. In this context, one actor stands out and has been involved in the development of this story since 1825: Diário de Pernambuco S.A.

This company is a member of the Diários Associados conglomerate. This conglomerate is described by Carneiro (1999) as an association in which each member has its own autonomy and legal identity as a corporation, with full administrative control of the company. Diário de Pernambuco S.A. is over 187 years old; making it the oldest journalism company in Latin America 
and the oldest regularly published newspaper in the Portuguese language (DUARTE, 2005). It currently publishes two newspapers: $O$ Diário de Pernambuco and Aqui PE.

According to the research of Ipsos Marplan (a Brazilian research company and a member of the international group Ipsos) from October 2010 to September 2011, the Diário had over 310,000 readers, equal to 51\% of the AB social class (upper and middle class); 124,000 have a university education and $69 \%$ are part of the economically active population. The Aqui PE, first published in August 2008, already has over 450,000 readers, with $60 \%$ belonging to social class C (working class).

From the first edition of the Diário de Pernambuco, on 7 November 1825, the main focus of the newspaper was clear: to print commercials. Therefore, since its foundation it has been dedicated more towards marketing and news. It did not stand aloof from politics, but gave priority to its advertising.

\section{ANALYSIS OF RELATIONSHIPS BETWEEN DYNAMIC CAPABILITIES AND INSTITUTIONS}

Each practice is described and analyzed in an attempt to identify them as dynamic capabilities and detect the influence of institutional factors in the structuring of each one:

Project to divulge the newspaper in schools - The Reader of the Future Program has been developed to encourage the use of the newspaper in the classroom for over fifteen years, using it as a teaching resource to help prepare new readers and collaborate with social and cultural development.

The organizational practice of the "reader of the future" is a way of shaping the new "rules of the game" (TEECE, 2007, p. 1321 ) in the market, attracting new readers and increasing the current and future circulation of the newspaper. In this sense, the "reader of the future" can be considered as dynamic capabilities in accordance with Teece (2007).

It was also shown that the practice arose under the aegis of social responsibility, guided by the National Newspaper Association (Associação Nacional de Jornais [ANJ]). The Newspaper in Schools program (PJE) is run by the ANJ in pursuit of "educational, business and social interests" (ANJ, 2008, p. 31).

Regarding social responsibility, Campbell (2007) demonstrates that the relationship between economic conditions and the behavior of companies is mediated by institutional factors: public and private regulations, the presence of organizations that monitor the company's behavior, institutionalized norms within the organization itself, shared behaviors of companies and the dialogue between companies and their stakeholders.

The reader of the future constituted a materialization of the social behavior of the actors involved with Diário de Pernambuco S.A., based on conformity to socially constructed patterns (BERGER and LUCKMANN, 1967), with consequently strengthened legitimacy.

Therefore, there is a relationship between institutional factors and the dynamic capability of sensing and shaping the environment. This relationship can be found in the studies of Teece (2007), when he points out a series of constraints of the rules of the game in the market: regulators, standard-setting bodies, laws, social mores and business ethics.

The action of journalists in discovering new technologies - "Our reporters bring in new technologies." This was the response of one company director, and journalists, when asked about the systematization of processes to discover new technologies that appear in the field of journalism.

At Diário de Pernambuco S.A., there is no specific sector for this type of action, such as the Research \& Development sector found in some companies. However, as a response of the Directors, the "non-existence of a sector does not mean that knowledge of what goes on out there is not updated in terms of new technology for journalism". The practice is not systematized, but it occurs through the newspaper's own activity when it produces information, i.e., the news.

The practice enables the detection of aspects of dynamic capability not only embedded in the drive for opportunities and threats , such as simple data found in the environment (TEECE, 2007), but as results of the process of subjective interpretation of information produced by the company itself. As stated by Vasconcelos (2004, p. 165), "the environment is how people look 
at and select relevant events, discarding other events as insignificant." Thus, the practice is reflected in a cultural structure that is reproduced by the company in its ongoing search for new technologies, using its interpretation of the social reality of journalism, supported by coherent interpretative schemas, demonstrated by the management of the newspaper, mainly in the incentives of the director of publications and the passion for technology shown by the General Director.

Participation at ANJ events - The National Newspaper Association (ANJ) was founded in 1979, and by August 2012 its membership included companies responsible for over $90 \%$ of newspaper circulation in Brazil. The importance of this association to Brazilian journalism can be seen in academic works such as that of Dorneles (2009). It is also evident from an interview conducted during the primary data collection for this paper with the writer and poet Gladstone Vieira Belo, vice-president of the Diário de Pernambuco, who has worked in journalism for over forty years.

\begin{abstract}
"Investigating a journalism company is a complicated task. We are conservative by nature. But a lot has changed since the foundation of the ANJ. In the old days, newspaper owners did not even want to meet each other on the streets. With the ANJ, businessmen meet, talk, attend lectures and discuss what is new and what is uncomfortable. To know about journalism in Brazil today, all you have to do is seek out the ANJ." (Belo, Gladstone).
\end{abstract}

The ANJ acts as a union, setting the rules for print media and being concerned with the professional code of ethics. Member companies are required to sign and obey the association's Code of Ethics. The Diário de Pernambuco has been a member of the association since day one, the reason for this being that through an exchange of experiences, the sharing of innovations and cooperation between companies, newspapers can develop as diversely as possible (ANJ, 2011). This is in line with the lessons of dynamic capabilities of Teece (2007) when he highlights the establishment of connections between companies and corporations to conduct wider studies concerning technological opportunities and consumer needs.

Furthermore, this is clearly a case of the development of an "organizational field", a central concept for institutional analysis (DIMAGGIO and POWELL, 1991), considered by Scott $(2001 ; 2008)$ as the highest level of significance to the institutional theory. The ANJ represents "a community of organizations that partakes of a common meaning system and whose participants interact more frequently and fatefully with one another than with actors outside the field." (SCOTT, 2001, p. 207-208).

Development of Aqui PE - In 2008, the administration of Diário de Pernambuco S.A. launched a new form of print media, the Aqui $P E$ newspaper. This is a tabloid that is easy and quick to read, low in price and focuses a great deal on sport and entertainment.

The report of the ANJ published in August 2006 highlights a number of Brazilian companies launching newspapers aimed at a public with less buying power. According to the Circulation Verification Institute (IVC), the main agency for auditing sales of print media in Brazil, the so-called popular press grew $7 \%$ (seven percent) in 2005. These popular newspapers include the Aqui-MG, founded in 2005 in Belo Horizonte and the Aqui-DF, founded in 2006 in Brasilia, both of which are members of the Diários Associados conglomerate.

After investigating reading habits, as requested by the IVC, and visits to journalism companies that were members of Diários Associados, fourteen employees and five trainees began working for the Aqui PE, which began to circulate from Monday to Friday. Its circulation grew to 10,000 copies by the end of 2008, with the average rising to 39,039 by December 2011. In 2016, both newspapers, the physical and the digital are integrated.

Regarding "the capacity of an organization is to purposefully create, extend or modify its resource base" (HELFAT, FINKELSTEIN, MITCHEL et al., 2007, p. 4), this was what happened at Diário de Pernambuco S.A. It was done by exploiting its secular competence for journalism for the well-off and using its printing presses, logistics, financial administration and other tangible, intangible and human assets to begin a new business.

On the other hand, the development of a mimetic isomorphism can be perceived, and explained in the institutional theory (DIMAGGIO and POWELL, 1983). The presence of this type of isomorphism materialized in the creation of the Aqui PE as it did in the Aqui $B H$ and Aqui $D F$, for the purpose of minimizing the uncertainty caused by the institutional demands of the 
rapidly changing reading habits of the more privileged economic classes, which resulted in a fall in the circulation of the Diário de Pernambuco.

Practice of online journalism - Diário de Pernambuco S.A. launched an online version of the printed newspaper on 4 July 1997, according to the newspaper's own files. The name of the home page was DPNet. In addition to a copy of some of the stories from the printed newspaper, organized as hypertexts, it also offered some services of the Diários Associados in Recife. In 2000, the Diário de Pernambuco launched an exclusive page and later, in 2008, it broadened its coverage of the news in real time. In 2012, other innovations enabled greater interaction with the reader. All of these actions constituted a complete strategic process in response to the new technologies brought by the internet.

The immediate action, of launching a web page in 1997, shows that the management of the company recognized the internet as an opportunity. This immediacy is more obvious because it was only in that same year that the infrastructure for accessing the internet was consolidated in the state of Pernambuco. Therefore, as soon as it was possible to have a website, the company launched one.

After launching DPNet, the company followed the lessons of Teece, Pisano e Schuen (1997), mobilizing resources, developing and reconfiguring competencies for dealing with equipment and computer programs necessary for making a digital version of the product that had been manufactured by the company for so long: information.

The fact that the company recognized the opportunity was shown in the words of the vice-president: "the internet ... was always viewed by the directors of the Diário de Pernambuco as a promising technological innovation".

However, the changes made by the company were already taking place at other newspapers in a number of locations around Brazil and the world (BOCZKOWSKI, 2004; RIGHETTI and QUADROS, 2007) with full development of adequate skills that were diffused and assimilated by other companies through journalistic associations, events and book publications. All of this constituted a process of the institutionalization (SCOTT, 2008) of a new journalistic practice: online journalism.

At Diário de Pernambuco S.A. the changes were so recent that there were no human resources available for them, as it was the first company in the region to launch a website. Therefore, the solution was to use the company's own members of staff who were interested in the subject to develop the necessary skills. This meant finding the concepts of "firm-specific" assets (TEECE et al., 1997, p. 518), as the new skills did not exist in the market, and would have to be constructed since they could not be bought.

In 2008, when the company launched its own specific website at www.diariodepernambuco.com.br with the company's name, "the website bore the name of the oldest newspaper in Latin America, with all of its reputation that had been built for over 180 years". This declaration and others like it were uttered by the directors who were interviewed.

In 2012, with the announcement of new changes, the Diário de Pernambuco had a pattern of activity that had been learned by the organization (ZOLLO and WINTER, 2002), with which the company systematically generated and modified its operating routines in the practice of online journalism.

Thus, when analyzing the practice of online journalism at Diário de Pernambuco S.A., one perceives the development of dynamic capabilities conditioned by institutionalization processes of knowledge and competencies.

Continued practice of convergence - The convergence of the two types of journalism is "the realm of possibilities when cooperation occurs between print and broadcast for the delivery of multimedia content through the use of computers and the internet" (LAWSON-BORDERS, 2003, p. 91). It enables journalistic content to be distributed in several forms at different times.

According to documents in the files of Diários Associados, since August 2008 the Diário de Pernambuco has announced its incorporation into the worldwide trend of the convergence of its printed and online journalism: "the copy writers of one and the other, which had previously occupied separate spaces, will now be working together, sharing content and producing multimedia material." (DIÁRIOS ASSOCIADOS, 2008, p. 1).

Stephen Quinn (2005), when publishing his Convergent Journalism emphasized that the process is slow and depends on a great deal of training because it is directly linked to organizational culture. 
At Diário de Pernambuco S.A., with the digital and print versions sharing the same space since 2008, observations made during visits to the newspaper show that the convergence of the media has greatly advanced. However, according to statements from journalists and directors of the company, in the early years there were considerable difficulties because the new process also depended on changes in the attitudes of people used to the old routines and other equipment and software.

In the convergence, there is cooperation between resources, competencies and capabilities, for a strategic purpose, defined by Teece (2007) as "cospecialized assets" (p. 1339). In this sense, commitment, cooperation and cultural changes are also highlighted (LAWSON-BORDERS, 2003), becoming a specific process of the company. Commitment, cooperation and cultural changes are not sold on the market. Therefore, they must be built during the structuration of the process. Thus, the full convergence of media at the Diário de Pernambuco has become idiosyncratic (HELFAT, FINKELSTEIN, MITCHEL et al., 2007; TEECE, 2007; TEECE, PISANO e SCHUEN, 1997).

Another aspect pertaining to dynamic capabilities becomes obvious regarding the dynamic of the coordination of two types of distinct competencies: the ambidexterity suggested by O'Reilly and Tushman (2008), i.e., the simultaneousness of (a) the exploitation of the competency of the production of print media, resulting from a secular learning process, with incremental innovations, above all of a company that is over 186 years old; with (b) the exploration of online journalism running at full steam with the diversity of the new technologies that emerge. This means a "meeting of the old and new", as shown by Raviola (2010, p. 262) when looking into the changes taking place in the institution of "the production of news" by the largest journalism company in Italy, Sole-24 Ore.

Therefore, there is a phenomenon in which the stability of the old print media converges with the change in the drive for new online journalism. In this case, change and stability are not paradoxes. They do not need to be mutually exclusive, but can strengthen each other in a dynamic of duality (FARJOUN, 2010; GIDDENS, 1993).

\section{INSTITUTIONAL FACTORS}

The organizational practices that revealed the presence of dynamic capabilities were conditioned by mechanisms and factors that extrapolated intentions, expectations and planning by the company's board of directors. These are institutional factors that appear both in internal activities and in the environment of organizational business.

In none of the practices was found resistance to the pressures resulting from the advent of the internet. The relevant aspects where isomorphic mechanisms, managerial interpretations, new rules, permeability to change and shared logic concerning finding solutions to exploit the opportunities of the internet in the best way possible. This began a trend towards quickly shaping a new environment, or conformity to institutional constraints.

\section{CONCLUSION}

The study sought to analyze the technical and institutional responses in the perspective of dynamic capabilities in the light of environmental changes in the sector at the oldest Brazilian newspaper. It also sought to prove the relationship between institutions and dynamic capabilities and verify the influential dynamic between them based on an analysis of strategic practices.

In the context of rapid technical and institutional development, and following the model suggested by the study, the strategic practices of Diário de Pernambuco S.A. were examined. Capabilities were revealed that enabled it to survive through the technological and institutional changes it has faced throughout its 186 -year history.

The strategic practices under study, such as making the newspaper known at schools, showed the influence of institutions of a normative order, social responsibility, greater legitimacy and at the same time a higher capacity of the organization to shape its business environment.

The recurring efforts of journalists to discover new technologies were reflected in a cultural structure that is reproduced at the company in its drive for the continuous use of new technologies. This structure is based on the interpretations of the 
journalists themselves regarding the social reality of the field of journalism, supported by the coherent interpretative schemata of some managers.

The capacity to develop a new product and a new business in the form of the Aqui PE newspaper was aided by mimetic mechanisms of isomorphism. The newspaper was conceived in the likeness of Aqui BH and Aqui DF in order to reduce the uncertainty caused by institutional demands of the rapidly changing reading habits of people in higher income brackets, which led to the drop in the circulation of the Diário de Pernambuco.

An analysis of the development of online journalism at the Diário de Pernambuco showed the dynamic capability for taking advantage of the opportunities offered by the internet, but conditioned by processes of the institutionalization of knowledge and competencies. This learning dynamic occurred externally, through interaction with other organizations in Brazil and around the world, and in the spread of knowledge in the professional environment of journalism (books, articles). It also occurred internally, with members of staff who were interested in the subject seeking knowledge and developing the necessary skills.

Another conclusion that resulted from the development of online journalism was the presence of the legitimacy of a secular brand to facilitate the capacity for creating a new resource, the new website, www.diariodepernambuco.com.br, in 2008. As it bore the name of the well-known newspaper, it was an immediate success, according to the interviewees.

An analysis of the "converging media" at Diário de Pernambuco S.A. showed that this practice occurred through the development and use of "co-specialized" assets or complementary resources in the production of the print and digital newspaper. Likewise, this convergence was found to require "ambidexterity" within the organization, or the coordination of two very different types of competencies: exploration and exploitation. Both the use of co-specialized assets and ambidexterity constituted dynamic capabilities, in accordance with the literature.

In short, it has been noted that the challenges introduced by the internet materialize not only with rapid technological changes but also with institutional modification, as seen in the changes in centuries old reading habits and the changes in how the age old practice of journalism is conducted, in addition to other social and political changes.

The case showed that organizational practices concerning the presence of dynamic capabilities were manifesting and being conditioned by factors that extrapolated intentions, expectations, planning and the skills of the board of directors. Institutional factors of a political, cultural and contextual nature were found, mediated by the interpretations and capacity of agents, isomorphic mechanisms of institutionalization and deinstitutionalization that manifested both in internal activities and the organizational business environment, interfering with changes in the company. As Lowrey (2011, p. 64) affirm, "institutionalist tendencies dominate decision-making about product change" in journalism sector.

An important theoretical finding revealed during the research has to do with the definition of dynamic capabilities. In the definition of Helfat, Finkelstein, Mitchel et al. (2007), the term purposefully could be removed as a suggestion, as it reflects a degree of intention, even if not totally explicit. Dynamic capabilities originate in the capacity for agency, in the power to intervene in the course of events or in the state of things without necessarily having any intention. These capabilities of the agents can exist before they become intentions and, according to the relationships found in this work, the dynamic capabilities were greatly conditioned by the presence of institutions. This finding emphasize what institutional logic help to explain, as mentioned by Kor and Mesko (2013) as dominant logic, in creating and sculpting the managerial team's absorptive capacity, which in turn shapes the team's adaptive capacity.

However, if purposefully (GIDDENS, 1993, p. 82) is distinct from the concept of intention, as it is according to English and Portuguese dictionaries, insinuating a "tendency to refer to longer-term ambitions" (GIDDENS, 1993, p. 82), then the term can continue to be part of the definition as long as it is suitably explained.

This was the beginning of a drive to gauge the relationship of institutions with dynamic capabilities involving the integration of two fields of literature. In practice, the conclusion that is reached is that the survival and even the growth of some journalism firms is due to the constant pursuit of the value of quality information as an institutional pillar of journalism, both on paper and online. However, companies cannot only react to reality. They must take the same shape as the environment so that they can also shape it, creating potentials for their organizational capability to reinvent journalism. 
Some recommendations can be made in order to facilitate and encourage future studies. The findings require validation through further quantitative and qualitative studies. These studies should be specific, i.e., focus on a single organizational practice in the same field or in other fields in which the influence of institutions is evident. Thus, future research should focus exclusively on the intended role of dynamic capabilities, but should not neglect institutional influence. In this way, more arguments will arise for the proposed conceptual modification.

The relationships between the constructs specified in this study could be enriched by breaking down the construct of the institutions into regulatory, normative and cultural-cognitive aspects, as shown in the theoretical model for the case study. However, these institutional categories should be outlined in detail in future studies.

The final stage of this study returned to an issue that has been relevant to this work since the inception of the project: how can journalism firms survive in times of challenges resulting from rapid social and technical development?

The theoretical and empirical findings suggest an answer, at least for the company in question. What has enabled the company to survive and even grow is its constant drive for the value of quality information as an institutional pillar of journalism. 


\section{REFERENCES}

ALBUQUERQUE FILHO, J. B.; MACHADO-DA-SILVA, C. L. Práticas Organizacionais e Estrutura de Relações no Campo do Desenvolvimento Metropolitano. Revista de Administração Contemporânea, v. 13, n. 4, p. 626-646, Oct./Dec. 2009.

ALCADIPANI, R. O Declínio dos Jornais. GV Executivo, v. 6, p. 30-35, 2007.

AREND, R.; BROMILEY P. Assessing the dynamic capabilities view: spare change, everyone? Strategic Organization, v. 7, n. 1, p. 75-90, 2009.

ANJ - Associação Nacional de Jornais. Relatório de atividades 2004/2006. Available at: <http://www.anj.org.br/wp-content/ uploads/rel_ANJ_2004_2006\%20.pdf>. Accessed on: Oct. 6, 2014.

ANJ - Associação Nacional de Jornais. Relatório de responsabilidade social 2006/2008. Available at: <http://www.anj.org.br/comite/ responsabilidade-social/relatorio-de-respons-social/relatorio\%20 social\%202008.pdf>. Accessed on: Oct. 6, 2014.

ANJ - Associação Nacional de Jornais. Estatuto social. Available at: <http://www.anj.org.br/quem-somos/estatuto/ANJ_ESTATUTO_ aprovado_\%20AssembleiaGeral.pdf>. Accessed on: Oct. 6, 2014.

BAGOZZI, R. P.; EDWARDS, J. R. A general approach for representing constructs in organizational research. Organizational Research Methods, v. 1, n. 1, p. 45-87, Jan. 1998.

BARBOSA, M. História Cultural da imprensa: Brasil - 1900-2000. Rio de Janeiro: Mauad X Editora Ltda., 2007.

BARDIN, Laurence. Análise de Conteúdo. Lisboa: Edições 70, LDA, 2007.

BARNEY, J. B. Firm resources and sustained competitive advantage. Journal of Management, v. 17, n. 1, p. 99-120, 1991.

BARNEY, J. B. Gaining and Sustaining Competitive Advantage. Massachussets: Addison Wesley, Reading, 1996.

BERGER, P. L.; LUCKMANN, T. A construção da realidade. 25. ed. Petrópolis: Vozes, 2005.

BOCZKOWSKI, P. J. Digitizing the News: Innovation in Online Newspapers. Cambridge, MA: The MIT Press. 2004.

CAMPBELL, J. L. Why would corporations behave in socially responsible ways? An institutional theory of corporate social responsibility. Academy of Management Review. v. 32, n. 3, p. 946-967, 2007.

CARNEIRO, Glauco. Brasil, primeiro: história dos Diários Associados. Brasília: Fundação Assis Chateaubriand, 1999.

CRESWELL, J.W. Research desing: qualitative, quantitative and mixed methods approaches. 2. ed. London: Sage Publications, 2002.

DEEPHOUSE, D. L. Does isomorphism legitimate. Academy of Management Journal. v. 39, p. 1124-1139, 1996.

DIÁRIOS ASSOCIADOS. O novo projeto do Diário de Pernambuco, 2008. Available at: <http://www.diariosassociados.com.br/file/0408. pdf> Accessed on: Oct. 6, 2014.
DIMAGGIO, P.; POWELL, W. W. The iron cage revisited: institutioinal isomorphism and collective rationality in organizational field. American Sociological Review, v. 48, n. 2, p. 147-160, 1983.

DIMAGGIO, P.; POWELL, W. W. Constructing an organizational fields as a professional project: US art museums, 1920-1940. In: POWELL, W.W.; DIMAGGIO, P. J. (Eds.). The New Institutionalism in Organizational Analysis. Chicago: University of Chicago Press, 1991. 267-292 p.

DORNELLES, B. O futuro do jornal. FAMECOS, Porto Alegre, n. 40, p. 63-67, 2009.

DOSI, G.; NELSON R. R.; WINTER S. G. (Eds.). The Nature and Dynamics of Organizational Capabilities. Oxford: Oxford University Press, 2009. 389 p.

DUARTE, J. A História Contada pelo Diário - A Praça Forte da Liberdade. Brasília: Fundação Assis Chateaubriand, 2005.

EISENHARDT, K. M; MARTIN, J. A Dynamic capabilities: What are they? Strategic Management Journal, v. 21, n. 10/11, p. 11051121, 2000.

FARJOUN, M. Beyond dualism: stability and change as a duality. Academy of Management Review. v. 35, n. 2, p. 202-225, 2010.

FIELD, A. Descobrindo a Estatística Utilizando o SPSS. 2. ed. Porto Alegre: Artmed, 2009.

GALASKIEWICZ, J. the structure of community organizational networks. Social Forces, v. 57, n. 4, p. 1346-1364, 1979.

GIDDENS, A. New rules of sociological method. Stanford: Stanford University Press, 1993.

GIDDENS, A. A constituição da sociedade. 2 ed. São Paulo: Martins Fontes, 2003.

HELFAT, C. E. et al. Dynamic capabilities: understanding strategic change in organizations. Oxford: Blackwell, 2007.

HELFAT, C. E.; PETERAF, M. A. Understanding dynamic capabilities: progress along a developmental path. Strategic Organization. v. 7, n. 1, p. 91-102, 2009.

HOLFELDT, A. Conceito e história do Jornalismo brasileiro. Revista de Comunicação [recurso eletrônico] / Antonio Hohlfeldt, Rafael Rosinato Valles. Porto Alegre: EDIPUCRS, 2008.

JEPPERSON, R. L. Institutions, institutional effects, and institutionalism. In: POWELL, W. W.; DiMAGGIO P. J. (Eds.). The new institutionalism in organizational analysis. Chicago: The University of Chicago Press, 1991. 143-163 p.

LOWREY, W. Institutionalism, News Organizations and Innovation. Journalism Studies, v. 12 n. 1, p. 64-79, 2011.

KOR, Y. Y.; MESKO, A. Dynamic managerial capabilities: configuration and orchestration of top executives' capabilities and the firm's dominant logic. Strategic Managerial Journal, v. 34 n. 2, p. 233-244. 2013. 
KUCINSKI, B. Jornalismo na era virtual: ensaios sobre o colapso da razão ética. São Paulo: Editora Unesp, 2005.

LAWSON-BORDERS, G. Integrating New Media and Old Media: Seven Observations of Convergence as a Strategy for Best Practices in Media Organizations. The International Journal on Media Management, v. 5, n. 2, p. 91- 99, 2003.

LEIH, S.; TEECE, D. Campus Leadership and the Entrepreneurial University: A Dynamic Capabilities Perspective. Academy of Management Perspectives, v. 30, n. 2, p. 182-210, 2016.

MACHADO-DA-SILVA, C. L; FONSECA, V. S. da; CRUBELLATE, J. M. Estrutura, agência e interpretação: elementos para uma abordagem recursiva do processo de institucionalização. Revista de Administração Contemporânea, v. 9, n. edição especial, p. 09-39, 2005.

MARCH, J. G.; OLSEN, J. Rediscovering Institutions: The Organizational Basis of Politics, New York: Free Press, 1989.

MCCHESNEY, R.W; NICHOLS, J. The death and life of American journalism. Philadelphia, PA: Nation books, 2010.

McKAGUE, K. Dynamic capabilities of institutional entrepreneurship. Journal of Enterprising Communities: People and Places in the Global Economy, v. 5 n. 1, p. 11-28, 2011.

MARTINS, A. L.; LUCA, T. R. (Org.). História da imprensa no Brasil. São Paulo: Editora Contexto, 2008.

MELO, J. M. Jornalismo: compreensão e reinvenção. São Paulo: Editora Saraiva, 2009.

MEYER, P. The Vanishing Newspaper: saving journalism in the information age. 2. Ed. Columbia, USA: University of Missouri Press, 2009.

MEYER, J. W.; ROWAN, B. Institutionalized organizations: formal structure as myth and ceremony. America Journal of Sociology, v. 83. n. 2, p. 340-362, 1977.

MOREL, M. Os primeiros passos da palavra impressa. In: MARTINS, A. L.; LUCA, T. R. (Org.). História da imprensa no Brasil. São Paulo: Editora Contexto, 2008. 23-43 p.

NELSON, R. R.; WINTER S. G. An Evolutionary Theory of Economic Change. Cambridge, Massachusetts: The Belknap Press of Harvard University Press, 1982.

OBSERVATÓRIO DA IMPRENSA. 200 anos de Imprensa no Brasil. 2008. Available at: <http://www.observatoriodaimprensa.com.br/ download/488MCH002.pdf>. Accessed on: Oct. 06, 2014.

OLIVER, C. Strategic responses to institutional processes. Academy of Management Review, v. 16, n. 1, p. 145-179, 1991.

OLIVER, C. The antecedents of deinstitutionalization. Organization Studies, v. 13, n. 4, p. 563-588, 1992.

O'REILLY, C. A.; TUSHMAN, M. L. Ambidexterity as a dynamic capability: Resolving the innovator's dilemma. Research in Organizational Behavior, v. 28, p. 85-206, 2008.

ORTRIWANO, G. S. Radiojornalismo no Brasil: fragmentos de história. Revista USP, n. 56, p. 66-85, Dez./Fev. 2002-2003.
PERIN, M. G; SAMPAIO, C. H; FALEIRO, S. N. O impacto da orientação para o mercado e da orientação para aprendizagem sobre a inovação de produto: uma comparação entre a indústria eletroeletrônica e o setor de ensino universitário de Administração. Revista de Administração Contemporânea, v. 8, n.1, p. 79-103, Jan./Mar. 2004.

PISANO, G. P. In Search of Dynamic Capabilities: In: DOSI, G.; NELSON R. R.; WINTER S. G. (Eds.). The Nature and Dynamics of Organizational Capabilities. Oxford: Oxford University Press, 2000.

PORTER, M. E. Estratégia Competitiva. 2. ed. Rio de Janeiro: Editora Campus, 2004.

PRONEWS. Diario na vanguarda digital, ed 134, 2011. Retrieved from http://www.revistapronews.com.br/siteantigo/anteriores/ detalhe/456/diario-na-vanguarda-digital.html

RAVIOLA, E. Paper meets Web: How the institution of news production works on paper and online. $293 \mathrm{f}$. Dissertation Series No. 065, Jönköping International Business School. Suécia: ARK Tryckaren AB, 2010.

RIGHETTI, S.; QUADROS, R. Inovação tecnológica, formação de competências e diversificação no mercado da comunicação: a introdução da internet em dois grupos brasileiros de mídia impressa. In: XXX Congresso Brasileiro de Ciências da Comunicação, INTERCOM 2007 - Sociedade Brasileira de Estudos Interdisciplinares da Comunicação,-Santos - Aug. 29 - Sept. 2, 2007.

SCOTT, W. R. Institutions and organizations: ideas and interests. 3. ed. Thousand Oaks, California: Sage Publications, 2008.

SCOTT, W. R et al. Institutional change and healthcare organizations. Chicago: The University of Chicago Press, 2000.

SODRÉ, N. W. História da Imprensa no Brasil. São Paulo: Mauad, 1994.

SUCHMAN, M. C Managing legitimacy: Strategic and institutional approaches. The Academy of Management Review. v. 20, n. 3, p. 571-610, jul. 1995.

TEECE, D. J. Explicating dynamic capabilities: the nature and microfoundations of (sustainable) enterprise performance. Strategic Management Journal, v. 28, n. 13, p. 1319-1350, 2007.

TEECE, D. J.; PISANO, G.; SCHUEN, A. Dynamic Capabilities and Strategic Management. Strategic Management Journal, v. 18, n.7, p. 509-533, 1997.

TOLBERT, P. S.; ZUCKER, L. G. A Institucionalização da Teoria Institucional. In: CLEGG, S. et al. (Org.). Handbook de Estudos Organizacionais, modelos de análise e novas questões em estudos organizacionais. São Paulo: Atlas, 1999. v. 1.

VASCONCELOS, F. C. A Institucionalização das estratégias de negócios: $O$ caso das start-ups na internet brasileira em uma perspectiva construtivista. Revista de Administração Contemporânea. v.8, n. 2, p. 159-179, 2004.

WERNERFELT, B. A resource-based view of the firm. Strategic Management Journal, v. 5, n. 2, p. 171-180, 1984.

ZOLLO, M.; WINTER S. G. Deliberate Learning and the Evolution of Dynamic Capabilities. Organization Science, v. 13, n. 3, p. 339-351, 2002. 
José Bonfim Albuquerque Filho

PhD in Administration from Universidade Federal do Paraná (UFPR), Brazil; Postgraduate degree in Military Applications from Escola de Comando e EstadoMaior do Exército (ECEME), Brazil; Executive-Coach, certified by The International Association of Coaching-IAC, USA. E-mail: jbonfimaf@gmail.com

\section{Sergio Bulgacov}

PhD in Administrtion from Escola de Administração de Empresas de São Paulo (FGV EAESP); Adjunct Professor at FGV EAESP. E-mail: s.bulgacov@gmail.com

Márcia Ramos May

PhD in Administração from Universidade de São Paulo (USP); Adjunct Professor in the Postgraduate Program in Administration of Federal Universidade Federal do Paraná. E-mail: marciarmay@gmail.com 